\title{
Enhancement of seed quality and bioactive compound accumulation in sunflower sprouts by dielectric barrier discharge plasma treatment
}

\author{
Panumart Rithichai $^{\mathrm{a}, *}$, Yaowapha Jirakiattikul ${ }^{\mathrm{a}}$, Maneerat Singhawiboon ${ }^{\mathrm{a}}$, Nopporn Poolyarat ${ }^{\mathrm{b}, \mathrm{c}}$ \\ a Department of Agricultural Technology, Faculty of Science and Technology, Thammasat University, \\ Pathum Thani 12120 Thailand \\ b Department of Physics, Faculty of Science and Technology, Thammasat University, Pathum Thani 12120 \\ Thailand \\ c Center of Advanced Nuclear Technology, Thailand Institute of Nuclear Technology (Public \\ Organization), Nakhon Nayok 26120 Thailand
}

*Corresponding author, e-mail: panumart@tu.ac.th

Received 19 Aug 2020

Accepted 10 May 2021

\begin{abstract}
Dielectric barrier discharge (DBD) plasma treatment has been reported to increase the quality of seeds and seedlings. In order to improve sprout quality, this study was conducted to investigate the effect of DBD plasma treatment on seed germination, vigour, growth, and bioactive compound content of sunflower (Helianthus annuus) sprouts. Two sunflower cultivars, Arfael and Jumbo, were treated using atmospheric DBD plasma at a discharge voltage of $20 \mathrm{kV}$ for 15, 30, 60, 120, and $240 \mathrm{~s}$. The non-treated seeds were used as control. The responses of seeds to the treatment depended on the exposure time and the cultivar. While the treatment stimulated seed germination and improved the vigour of the Jumbo cultivar at all exposure times, the Arfael cultivar responded only to exposures of $60 \mathrm{~s}, 120 \mathrm{~s}$, and $240 \mathrm{~s}$. Sprouts derived from $60 \mathrm{~s}, 120 \mathrm{~s}$, and $240 \mathrm{~s}$ DBD plasma treatments exhibited greater dry weight than those from other treatments. Moreover, the Arfael sprouts showed a higher bioactive compound level than the Jumbo sprouts. The DBD plasma treatments of both cultivars for $120 \mathrm{~s}$ and $240 \mathrm{~s}$ enhanced the accumulation of total phenolics and flavonoids. However, plasma treatment did not affect DPPH radical scavenging. The results from this study indicate that the $120 \mathrm{~s}$ DBD plasma treatment is effective in enhancing seed germination, growth, and bioactive compound of sunflower sprouts. This study is the first of its kind to illustrate the potential benefits of the DBD plasma treatment to enhance the quality of sunflower sprouts.
\end{abstract}

KEYWORDS: DBD plasma, flavonoid, germination, phenolic, sunflower sprout

\section{INTRODUCTION}

Dielectric barrier discharge (DBD) plasma is a nonthermal or cold plasma usually generated at low temperature and atmospheric pressure $[1,2]$. It induces changes in plant chemistry while causing only minor damage to biological materials [1,3-5]. Plasma treatment has been documented to improve seed performance and seedling growth in many plant species and is an attractive physical method, being chemical-free, environmentally friendly, quick, and non-destructive $[2,6]$. The field and laboratory germination of Lupinus angustifolius, Galega virginiana, and Melilotus albus seeds subjected to plasma for 10 to $15 \mathrm{~min}$ increased by 10-20\% compared with control [7]. The Mimosa caesalpiniafolia seeds subjected to DBD plasma at
$17.5 \mathrm{kV}$ for 3 min exhibited a germination percentage eight times that of the untreated seeds [8]. The Andrographis paniculata seeds treated to DBD plasma at $4250 \mathrm{~V}$ for $10 \mathrm{~s}$ and $5950 \mathrm{~V}$ for $20 \mathrm{~s}$ had significantly improved germination index [6]. Exposing Glycine max seeds to plasma at $80 \mathrm{~W}$ for $15 \mathrm{~s}$ enhanced the germination index by $14.66 \%$ and the vigour index by $63.33 \%$ over control [9]. The shoot length of the Raphanus sativus seedlings after DBD plasma treatment at $9.2 \mathrm{kV}$ for $180 \mathrm{~s}$ was $250 \%$ greater than control [10]. The sprouts of the 15-min non-thermal-plasma treated Triticum aestivum seeds showed higher growth than control [11]. DBD plasma also induces an increase in the concentration of bioactive compounds and is particularly effective at the seedling stage. The Spinacia oleracea seeds exposed to DBD plasma at 
$6 \mathrm{kV}$ for 30 to $60 \mathrm{~s}$ produced seedlings with high concentrations of chlorophyll and phenolics [12]. Significant increases in phenolic content have also been reported for T. aestivum and Capsicum annuum seedlings grown from seeds DBD-plasma-treated for $60 \mathrm{~s}$ and $120 \mathrm{~s}$, respectively $[13,14]$. The plasma response of plant species, it appears, depends on factors including the discharge voltage and duration of exposure.

An unhealthy diet is a behavioural risk factor associated with non-communicable diseases (NCDs), including cardiovascular conditions, cancers, chronic respiratory diseases, and diabetes. Vegetable sprouts, a good source of vitamins, minerals, antioxidants, and dietary fibre, are considered to be one of the functional foods $[15,16]$. Sprout cultivation requires no chemical treatment; it is simple and inexpensive. Being safe and healthy, sunflower (Helianthus annuus) sprouts are a popular green. However, the use of plasma treatment to promote the germination and accumulation of bioactive compounds in sunflower sprouts has not yet been reported. This study aimed to investigate the role of DBD plasma at different exposure times in sunflower seed germination and vigour. The growth, the total phenolic and flavonoid contents, and the DPPH radical scavenging of sunflower sprouts were recorded. DBD plasma treatment is a potentially useful alternative method for improving the bioactivity of this healthy food.

\section{MATERIALS AND METHODS}

\section{DBD plasma treatment}

DBD plasma was generated at atmospheric pressure between two parallel copper electrodes. Two glass plates were used as dielectric barriers. A gap between the two glass plates was set to $4 \mathrm{~mm}$. The discharge voltage and frequency supplied to the electrodes were fixed at $20 \mathrm{kV}$ and $5.5 \mathrm{kHz}$, respectively. The sunflower seeds were placed on the glass and exposed to atmospheric DBD plasma for $15,30,60,120$, and $240 \mathrm{~s}$. The non-treated seeds were used as control.

\section{Seed preparation}

The seeds of two sunflower cultivars, Arfael and Jumbo, were purchased from a wholesale market in the Pathum Thani Province, Thailand. They were sterilized using $1.5 \%(\mathrm{v} / \mathrm{v}) \mathrm{NaOCl}$ for $4 \mathrm{~min}$, then washed and soaked in tap water for $8 \mathrm{~h}$. All the tests were conducted immediately after the preparation.

\section{Seed germination and vigour tests}

The germination tests were conducted using four replications of 50 seeds. The seeds were germinated between rolled paper towels and placed in a germinator at $25{ }^{\circ} \mathrm{C}$ under fluorescent lighting for $8 \mathrm{~h}$. The normal seedlings were evaluated at 4 and 10 days after sowing [17]. The germination percentage and germination percentage at first count (first count) were calculated. For mean time to germination (MTG), the seeds were germinated under the same test conditions. The normal seedlings were counted daily until 10 days after sowing. The MTG was calculated as MTG $=\sum \mathrm{T}_{\mathrm{i}} \mathrm{N}_{\mathrm{i}} / \sum \mathrm{N}_{\mathrm{i}}$, where $\mathrm{N}_{\mathrm{i}}$ is the number of germinated seeds at time $T_{i}[18]$.

\section{Sprout growth}

One hundred seeds were seeded in $10 \times 5 \times 5 \mathrm{~cm}$ plastic boxes containing $3 \mathrm{~cm}$ in depth of moist peat moss. They were placed in a germinator at $25^{\circ} \mathrm{C}$ under fluorescent lighting for $8 \mathrm{~h}$. The sprouts were harvested $5 \mathrm{~d}$ after sowing, and the sprout length and fresh weight were recorded. To determine the dry weight, the sprouts were dried in a hot air oven at $50^{\circ} \mathrm{C}$ for $72 \mathrm{~h}$.

\section{Bioactive compound determination}

For extraction, the dried sprouts were powdered and macerated in 95\% ethanol, following the procedure of Worawattananutai et al [19]. The ratio of dry sample to ethanol was 1:10 weight by volume. The powder was macerated for $72 \mathrm{~h}$ and passed through filter paper. The residues were further macerated twice. The combined extracts were evaporated in the hot air oven at $50^{\circ} \mathrm{C}$ for $72 \mathrm{~h}$. The total phenolic and flavonoid contents of the extracts were measured, and the antioxidant activity was determined using the DPPH radical scavenging assay.

\section{Total phenolic content}

The total phenolic content was determined using Folin-Ciocalteu colorimetric method as described by Jirakiattikul et al [20]. The extract was dissolved in absolute ethanol to a concentration of $1 \mathrm{mg} / \mathrm{ml}$ and sonicated for $1 \mathrm{~min}$. Twenty $\mu \mathrm{l}$ of each sample was mixed with $100 \mu \mathrm{l}$ of 10 times diluted Folin Ciocalteu's reagent, then $80 \mu \mathrm{l}$ of $7.5 \% \mathrm{Na}_{2} \mathrm{CO}_{3}$ was added and the mixture was incubated in the dark at room temperature for $30 \mathrm{~min}$. Absorbance was measured in a microplate reader (Power Wave XS, Biotek) at $765 \mathrm{~nm}$. The total phenolic content was expressed as mg gallic acid equivalent (GAE)/g dry extract. 


\section{Total flavonoid content}

The total flavonoid content was assessed using a modified method of Zhu et al [21]. The extract was dissolved in absolute ethanol to a concentration of 1 $\mathrm{mg} / \mathrm{ml}$ and sonicated for $1 \mathrm{~min}$. Five hundred $\mu \mathrm{l}$ of each sample was mixed with $75 \mu \mathrm{l}$ of $5 \% \mathrm{NaNO}_{2}$ and left for $6 \mathrm{~min}$, then $150 \mu \mathrm{l}$ of $10 \% \mathrm{AlCl}_{3}$ was added and the mixture was left for 6 min. Finally, $500 \mu \mathrm{l}$ of $1 \mathrm{M} \mathrm{NaOH}$ and $275 \mu \mathrm{l}$ of distilled water were added, and the mixture was incubated at room temperature for $15 \mathrm{~min}$. Absorbance was measured in a microplate reader at $510 \mathrm{~nm}$. The total flavonoid content was expressed as $\mathrm{mg}$ catechin equivalent (CE)/g dry extract.

\section{Antioxidant activity}

The antioxidant activity was measured using the DPPH radical scavenging assay adapted from Yamasaki et al [22]. The DPPH solution was prepared by dissolving $12 \mathrm{mg}$ DPPH with $50 \mathrm{ml}$ ethanol. The extract was dissolved in absolute ethanol to a concentration of $1 \mathrm{mg} / \mathrm{ml}$, then $100 \mu \mathrm{l}$ of each sample was mixed with $100 \mu \mathrm{l}$ of DPPH solution and incubated in the dark at room temperature for $30 \mathrm{~min}$. Absorbance was measured in a microplate reader at $520 \mathrm{~nm}$. The percentage inhibition was calculated as $\%$ inhibition $=\left[\left(\mathrm{Abs}_{\text {control }}-\mathrm{Abs}_{\text {sample }}\right) / \mathrm{Abs}_{\text {control }}\right] \times$ 100. Here, $\mathrm{Abs}_{\text {control }}$ is the absorbance of the control, and $\mathrm{Abs}_{\text {sample }}$ is the absorbance of the test sample.

\section{Statistical analysis}

The experiments used a $2 \times 6$ factorial CRD with four replications. The data were analysed using the SPSS software. The mean separation was conducted by applying Duncan's multiple range test at $p \leqslant$ 0.05 .

\section{RESULTS}

The interaction effect of the cultivar and DBD plasma exposure time showed significant differences across all parameters, except for sprout dry weight and DPPH radical scavenging (Tables 1-3).

\section{Seed germination and vigour}

The Jumbo seeds exposed to the DBD plasma treatment exhibited germination percentages of $7.27 \%$ to $10.30 \%$ higher than that of control. In contrast, no significant difference with control was found for the Arfael seeds subjected to DBD plasma treatment at any exposure time. First count and MTG were used as indicators of seed vigour. First count of Jumbo seeds treated using DBD plasma at all the different exposure times exceeded that of control by $10.94 \%$ to $15.32 \%$. The Arfael seeds treated for $60 \mathrm{~s}, 120 \mathrm{~s}$, and $240 \mathrm{~s}$ were respectively 4.86\%, $6.94 \%$, and $7.64 \%$ above control. The Arfael seeds exposed for $120 \mathrm{~s}$ showed the lowest MTG, though this was not statistically different from the $15 \mathrm{~s}$, $30 \mathrm{~s}, 60 \mathrm{~s}$, or $240 \mathrm{~s}$ exposures, or the Jumbo seeds exposed for $240 \mathrm{~s}$. The longer MTG was observed in the Jumbo seeds exposed for $15 \mathrm{~s}$ to $120 \mathrm{~s}$ and the non-treated seeds of both cultivars (Table 1).

\section{Sprout growth}

The DBD plasma exposure for $60 \mathrm{~s}, 120 \mathrm{~s}$, and 240 $s$ increased the sprout length of the Arfael seedlings by $51.94 \%, 46.53 \%$, and $55.49 \%$, respectively, compared with control. The Jumbo sprouts were generally short, and only the $30 \mathrm{~s}, 60 \mathrm{~s}$, and $120 \mathrm{~s}$ DBD plasma treatments produced sprout lengths greater than control. The sprout fresh weight of the Jumbo seedlings showed significant increases of $15.91 \%, 22.48 \%$, and $13.95 \%$ over control when exposed to the DBD plasma for $30 \mathrm{~s}, 60 \mathrm{~s}$, and $120 \mathrm{~s}$, respectively. Following the DBD plasma treatment, the sprout fresh weight of 'Arfael' seedlings was below that of the control, with the exception of the $120 \mathrm{~s}$ treatment. The sunflower sprouts developed from the $60 \mathrm{~s}, 120 \mathrm{~s}$, and $240 \mathrm{~s}$ DBD plasma-treated seeds exhibited higher growth, as the sprout dry weight increased over control of $10.61 \%, 17.72 \%$, and $11.72 \%$, respectively. The sprout dry weights of the Jumbo seedlings were greater than those of the Arfael (Table 2).

\section{Bioactive compounds}

Compared with control, the DBD plasma exposure of $120 \mathrm{~s}$ and $240 \mathrm{~s}$ respectively enhanced the total phenolic content by $19.71 \%$ and $20.80 \%$ in Jumbo and $7.07 \%$ and $7.96 \%$ in Arfael. The optimal exposure times for improving the total flavonoid content differed between the cultivars. Compared with control, the Jumbo sprouts grown from the seeds treated for $15 \mathrm{~s}, 60 \mathrm{~s}$, and $240 \mathrm{~s}$ increased by $33.24 \%, 23.73 \%$, and $19.90 \%$, respectively. The Arfael sprouts grown from seeds treated for $30 \mathrm{~s}$ by $14.90 \%$, and for 120 s by $18.15 \%$. The inhibition percentage of DPPH was not statistically different among the DBD plasma treatments. Overall, Arfael showed stronger antioxidant activity than Jumbo (Table 3).

\section{DISCUSSION}

Seed germination and vigour are important for sprout cultivation. Pre-sowing treatment is usually 
Table 1 Germination percentage, first count, and mean time to germination (MTG) of the Jumbo and Arfael sunflower seeds subjected to DBD plasma treatments at different exposure times.

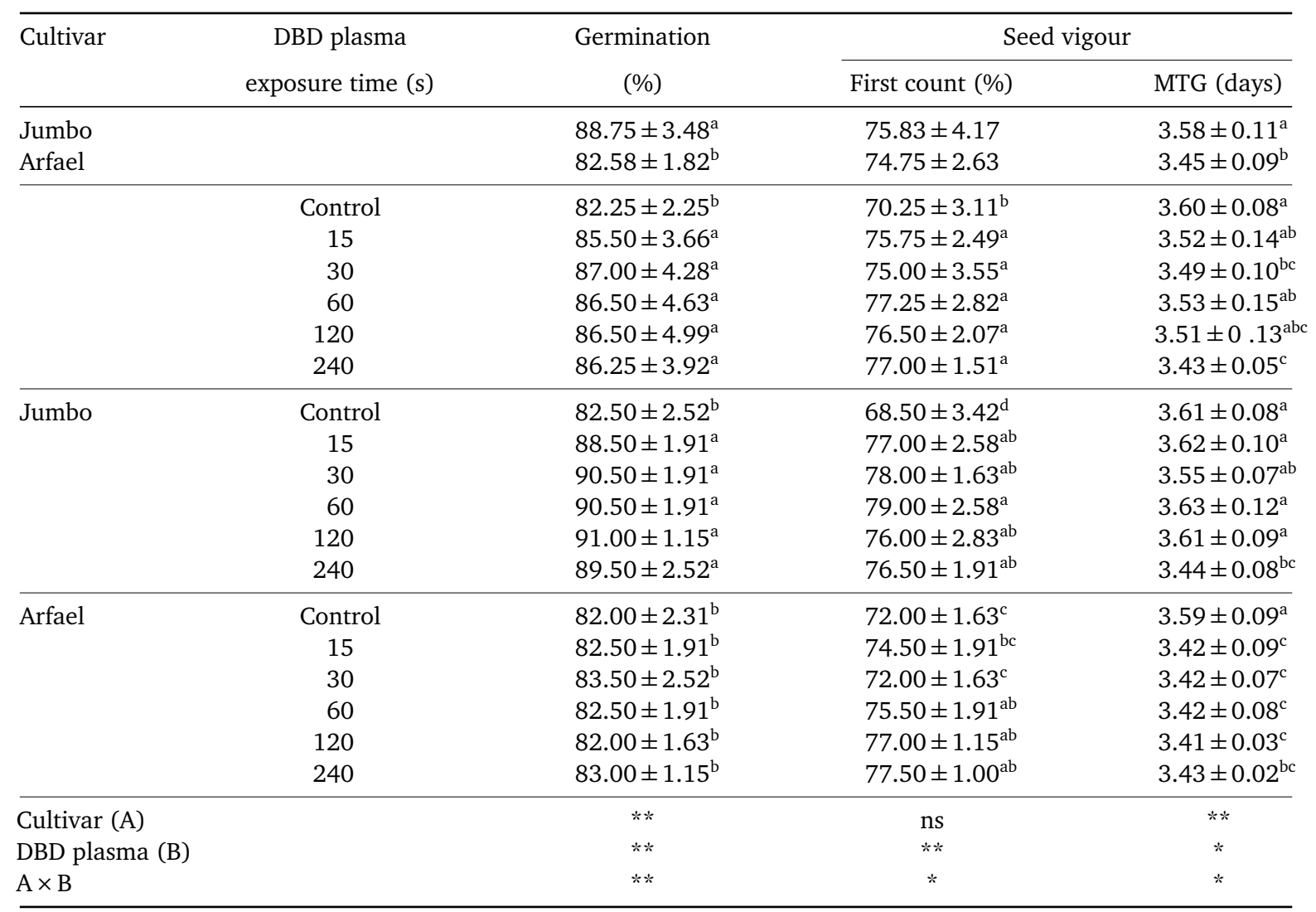

Means \pm SD within each column followed by the same letters are not significantly different at $p \leqslant 0.05$ level by DMRT; ns non-significantly different at $p>0.05 ; * *$ significantly different at $p \leqslant 0.01 ; *$ significantly different at $p \leqslant 0.05$.

required to increase sprout uniformity. Since it is quick, non-destructive, environmentally friendly, and requires no use of chemicals, cold plasma treatment is a widely-used method $[2,6]$. The response of the sunflower seeds to the DBD plasma treatment depended on the cultivar and the exposure time. The plasma treatment stimulated seed germination and increased the vigour of the Jumbo sprouts at all exposure times. Similar results have been reported for G. max seeds exposed to plasma at 80 W for $15 \mathrm{~s}$, enhancing seed germination by $14.66 \%$ and the vigour index by $63.33 \%$ compared with control [9]. The plasma treatment of Carthamus tinctorium increased the germination percentage by $50 \%$ over control while reducing germination time by $24 \mathrm{~h}$ [23]. In contrast, no significant difference was found in the germination percentage of the plasma treated Arfael seeds compared with control. However, the DBD plasma treatment for $60 \mathrm{~s}, 120$ $\mathrm{s}$, and $240 \mathrm{~s}$ increased the seed vigour. These results were in agreement with those reported for T. aestivum [11] and A. panuculata [6]. In both cases, plasma treatment improved only seed vigour. The effect of DBD plasma on seed germination and vigour is attributed to the modification of the physical structure of the seed coat. Šerá et al [24] demonstrated that longitudinal cracks appeared in the caryopsis surface of T. aestivum following plasma treatment. When the $C$. tinctorium seeds were plasma-treated, tiny holes occurred on the surface of the seed coat and a hilum with a soft structure developed [23]. The seed coat also became hydrophilic, improving wettability $[8,11]$ and increasing water imbibition and oxygen penetration $[6,9,12,23]$. Initial seed germination is usually characterized by a rapid uptake of water. Increased water absorption and gas exchange through the cracked seed coat enhances germination in the plasma-treated seeds.

Exposure to DBD plasma for $60 \mathrm{~s}, 120 \mathrm{~s}$, and $240 \mathrm{~s}$ resulted in the improvement of sunflower 
Table 2 Length, fresh weight, and dry weight of the Jumbo and Arfael sunflower sprouts derived from DBD plasmatreated seeds at different exposure times.

\begin{tabular}{|c|c|c|c|c|}
\hline Cultivar & $\begin{array}{c}\text { DBD plasma } \\
\text { exposure time (s) }\end{array}$ & $\begin{array}{l}\text { Length } \\
(\mathrm{cm})\end{array}$ & $\begin{array}{l}\text { Fresh weight } \\
\text { (mg/plant) }\end{array}$ & $\begin{array}{l}\text { Dry weight } \\
\text { (mg/plant) }\end{array}$ \\
\hline Jumbo & & $6.52 \pm 0.87^{b}$ & $225.08 \pm 34.54$ & $37.70 \pm 4.55^{a}$ \\
\hline \multirow[t]{7}{*}{ Arfael } & & $7.87 \pm 1.29^{\mathrm{a}}$ & $216.11 \pm 27.26$ & $25.45 \pm 3.96^{\mathrm{b}}$ \\
\hline & Control & $6.08 \pm 0.66^{\mathrm{d}}$ & $223.46 \pm 30.95^{\mathrm{ab}}$ & $29.86 \pm 9.26^{b c}$ \\
\hline & 15 & $6.60 \pm 0.61^{\mathrm{cd}}$ & $199.97 \pm 23.61^{b c}$ & $28.61 \pm 7.15^{c}$ \\
\hline & 30 & $7.05 \pm 0.49^{\mathrm{cb}}$ & $222.52 \pm 26.86^{\mathrm{ab}}$ & $29.44 \pm 5.07^{\mathrm{bc}}$ \\
\hline & 60 & $8.47 \pm 0.63^{\mathrm{a}}$ & $241.46 \pm 29.74^{\mathrm{a}}$ & $33.03 \pm 6.57^{\mathrm{ab}}$ \\
\hline & 120 & $7.59 \pm 1.33^{\mathrm{b}}$ & $240.62 \pm 20.22^{\mathrm{a}}$ & $35.15 \pm 6.65^{\mathrm{a}}$ \\
\hline & 240 & $7.37 \pm 1.99^{\mathrm{b}}$ & $195.56 \pm 28.23^{c}$ & $33.36 \pm 9.34^{\mathrm{ab}}$ \\
\hline \multirow[t]{6}{*}{ Jumbo } & Control & $6.26 \pm 0.77^{\mathrm{fg}}$ & $211.09 \pm 39.71^{\mathrm{bcd}}$ & $38.41 \pm 0.39$ \\
\hline & 15 & $6.10 \pm 0.34^{f g}$ & $215.99 \pm 14.4^{\mathrm{bcd}}$ & $35.01 \pm 1.89$ \\
\hline & 30 & $6.70 \pm 0.19^{\mathrm{def}}$ & $244.68 \pm 11.94^{\mathrm{ab}}$ & $34.05 \pm 1.23$ \\
\hline & 60 & $7.97 \pm 0.22^{\mathrm{bc}}$ & $258.56 \pm 15.00^{\mathrm{a}}$ & $38.15 \pm 2.39$ \\
\hline & 120 & $6.52 \pm 0.62^{\mathrm{ef}}$ & $240.55 \pm 27.57^{\mathrm{ab}}$ & $40.27 \pm 5.31$ \\
\hline & 240 & $5.56 \pm 0.47^{g}$ & $179.63 \pm 27.96^{\mathrm{d}}$ & $40.29 \pm 8.58$ \\
\hline \multirow[t]{6}{*}{ Arfael } & Control & $5.91 \pm 0.58^{\mathrm{fg}}$ & $235.83 \pm 15.83^{\mathrm{abc}}$ & $21.31 \pm 2.27$ \\
\hline & 15 & $7.11 \pm 0.27^{\mathrm{de}}$ & $183.94 \pm 20.17^{\mathrm{d}}$ & $22.22 \pm 2.54$ \\
\hline & 30 & $7.40 \pm 0.43^{\mathrm{cd}}$ & $200.35 \pm 15.18^{\mathrm{cd}}$ & $24.83 \pm 1.39$ \\
\hline & 60 & $8.98 \pm 0.46^{\mathrm{a}}$ & $224.37 \pm 32.54^{\mathrm{abc}}$ & $27.90 \pm 5.01$ \\
\hline & 120 & $8.66 \pm 0.84^{\mathrm{ab}}$ & $240.69 \pm 13.91^{\mathrm{ab}}$ & $30.02 \pm 2.19$ \\
\hline & 240 & $9.19 \pm 0.50^{\mathrm{a}}$ & $211.50 \pm 20.03^{\mathrm{bcd}}$ & $26.43 \pm 1.43$ \\
\hline Cultivar (A) & & $* *$ & ns & $* *$ \\
\hline DBD plasma (B) & & $* *$ & $*$ & $*$ \\
\hline$A \times B$ & & $* *$ & $*$ & ns \\
\hline
\end{tabular}

Means \pm SD within each column followed by the same letters are not significantly different at $p \leqslant 0.05$ level by DMRT; ns non-significantly different at $p>0.05$; * significantly different at $p \leqslant 0.01$; significantly different at $p \leqslant 0.05$.

sprout growth. These exposure times may stimulate the biochemical pathways during germination by triggering release of hormones including $\mathrm{GA}_{3}$ (gibberellin) and a range of hydrolytic enzymes [12]. The supporting nutrients stored in the seeds may then be utilized more effectively, hence enhancing plant growth $[9,12]$. The stimulation of plant growth by plasma treatment of seeds has been documented both in the seedling growth phase [9-11, 14, 25-27] and in the mature growth phase in the field $[25,28]$. Conversely, plasma treatment has been reported to reduce seedling growth in some plant species, including Fagopyrum aesculentum [29], T. aestivum, and Avena sativa [24].

The total phenolic and flavonoid enhancement of sunflower sprouts depended on the cultivars and the exposure time. Arfael sprouts had a higher level of bioactive compounds than Jumbo sprouts. Longer DBD plasma exposure times of $120 \mathrm{~s}$ and 240 s produced stronger responses. Plasma gen- erates reactive oxygen species (ROS), heat, nitric oxide, and UV radiation [13,27]. Šerá et al [24] proposed that ROS penetrates the seed coat and affects the metabolic processes of the cells. For selfprotection, each cell increases the accumulation of bioactive compounds. Our results were in agreement with the previous reports. Following the DBD plasma treatment of $S$. oleracea [12] and T. aestivum seeds [13] for 30-60 s and $60 \mathrm{~s}$, respectively, the seedlings exhibited significantly increased phenolic content. Iranbakhsh et al [14] demonstrated an $82.3 \%$ increase over control in the phenolic content of C. annuum seedling leaves grown from $120 \mathrm{~s}$ DBD plasma-treated seeds. Moreover, the sprouts derived from the DBD plasma-treated seeds are safe without microbial contaminations. Several reports have been documented in this issue; for instance, Mitra et al [30] exposed Cicer arietinum seeds to cold atmospheric plasma. Their results showed a significant reduction of natural surface microorgan- 
Table 3 Total phenolic content (TPC), total flavonoid content (TFC), and DPPH radical scavenging capacity of the Jumbo and Arfael sunflower sprouts derived from DBD plasma-treated seeds at different exposure times.

\begin{tabular}{|c|c|c|c|c|}
\hline Cultivar & $\begin{array}{l}\text { DBD plasma } \\
\text { exposure time }(\mathrm{s})\end{array}$ & $\begin{array}{c}\text { TPC } \\
\text { (mg GAE/g dry extract) }\end{array}$ & $\begin{array}{c}\text { TFC } \\
\text { (mg CE/g dry extract) }\end{array}$ & $\begin{array}{c}\text { DPPH radical } \\
\text { scavenging capacity (\%) }\end{array}$ \\
\hline Jumbo & & $60.35 \pm 6.17^{b}$ & $30.25 \pm 4.08^{b}$ & $90.78 \pm 3.23^{b}$ \\
\hline \multirow[t]{7}{*}{ Arfael } & & $91.83 \pm 3.56^{\mathrm{a}}$ & $44.96 \pm 4.65^{\mathrm{a}}$ & $93.42 \pm 1.55^{\mathrm{a}}$ \\
\hline & Control & $72.68 \pm 17.05^{c}$ & $33.69 \pm 9.05^{\mathrm{b}}$ & $91.64 \pm 3.64$ \\
\hline & 15 & $72.37 \pm 17.74^{c}$ & $37.35 \pm 4.31^{\mathrm{a}}$ & $92.92 \pm 3.09$ \\
\hline & 30 & $75.84 \pm 19.62^{\mathrm{b}}$ & $37.94 \pm 10.45^{\mathrm{a}}$ & $92.21 \pm 1.28$ \\
\hline & 60 & $72.69 \pm 18.21^{\mathrm{c}}$ & $39.19 \pm 7.85^{\mathrm{a}}$ & $90.66 \pm 4.49$ \\
\hline & 120 & $81.42 \pm 14.53^{\mathrm{a}}$ & $38.76 \pm 11.30^{\mathrm{a}}$ & $92.01 \pm 1.78$ \\
\hline & 240 & $82.12 \pm 14.67^{\mathrm{a}}$ & $38.68 \pm 8.61^{\mathrm{a}}$ & $93.15 \pm 1.30$ \\
\hline \multirow[t]{6}{*}{ Jumbo } & Control & $56.78 \pm 1.37^{\mathrm{d}}$ & $26.08 \pm 4.21^{\mathrm{f}}$ & $90.39 \pm 5.04$ \\
\hline & 15 & $55.82 \pm 1.25^{\mathrm{d}}$ & $34.75 \pm 2.81^{\mathrm{d}}$ & $90.77 \pm 1.04$ \\
\hline & 30 & $57.16 \pm 23.84^{\mathrm{d}}$ & $28.41 \pm 1.20^{\mathrm{ef}}$ & $91.54 \pm 0.50$ \\
\hline & 60 & $55.79 \pm 2.10^{\mathrm{d}}$ & $32.27 \pm 2.87^{\mathrm{de}}$ & $88.29 \pm 5.63$ \\
\hline & 120 & $67.97 \pm 2.97^{c}$ & $28.71 \pm 2.39^{\mathrm{ef}}$ & $90.53 \pm 1.13$ \\
\hline & 240 & $68.59 \pm 2.55^{c}$ & $31.27 \pm 4.66^{\mathrm{def}}$ & $93.17 \pm 1.82$ \\
\hline \multirow[t]{6}{*}{ Arfael } & Control & $88.59 \pm 1.54^{b}$ & $41.31 \pm 4.33^{\mathrm{bc}}$ & $92.89 \pm 1.13$ \\
\hline & 15 & $88.91 \pm 1.46^{\mathrm{b}}$ & $39.94 \pm 4.18^{c}$ & $95.07 \pm 2.98$ \\
\hline & 30 & $93.40 \pm 2.77^{\mathrm{a}}$ & $47.47 \pm 3.33^{\mathrm{a}}$ & $92.88 \pm 1.54$ \\
\hline & 60 & $89.58 \pm 2.85^{\mathrm{b}}$ & $46.12 \pm 2.75^{\mathrm{ab}}$ & $93.02 \pm 0.59$ \\
\hline & 120 & $94.86 \pm 1.43^{\mathrm{a}}$ & $48.81 \pm 4.78^{\mathrm{a}}$ & $93.50 \pm 0.42$ \\
\hline & 240 & $95.64 \pm 2.74^{\mathrm{a}}$ & $46.08 \pm 2.28^{\mathrm{ab}}$ & $93.14 \pm 0.80$ \\
\hline \multicolumn{2}{|c|}{ Cultivar (A) } & $* *$ & $* *$ & $* *$ \\
\hline \multicolumn{2}{|c|}{ DBD plasma (B) } & $* *$ & $*$ & ns \\
\hline \multicolumn{2}{|c|}{$\mathrm{A} \times \mathrm{B}$} & $* *$ & $* *$ & ns \\
\hline
\end{tabular}

ism contamination under $2 \mathrm{~min}$ and 5 min treatments. Butscher et al [4] also studied the impact of non-thermal plasma treatment for $5 \mathrm{~min}$ and $10 \mathrm{~min}$ on artificially applied Escherichia coli on Allium cepa, Medicago sativa, Lepidium sativum, and R. sativus seeds. The inactivation efficiency of $E$. coli, they concluded, increased with treatment time. Moreover, Štěpánová et al [5] showed that atmospheric pressure plasma treatment was able to reduce some of the microorganisms and pathogens affecting the seeds of Cucumis sativus and C. annuum.

The results from this study indicate that the DBD plasma exposure time of $120 \mathrm{~s}$ is optimal in enhancing the quality of sunflower seeds and sprouts. A high percentage of germination, short germination time, and non-pathogen contamination are the important seed quality factors for sprout production. Consequently, pre-sowing seed treatment is normally applied to produce high sprout quality. The seed treatment operated by physical technique requires specific equipment. In the case of DBD plasma equipment, it consists of the following components: a power supply system, US\$ 1000; electrode plates, US\$ 66.67; signal generator, US\$ 333.33; and high voltage coil, US\$ 100 . Thus, the starting cost of the DBD plasma equipment is US\$ 1500. For enhancing sprout quality, the appropriate exposure time of DBD plasma is $120 \mathrm{~s}$. Therefore, the operating cost of electric power $(0.5$ $\mathrm{kW} \times 0.03 \mathrm{~h} \times \mathrm{US} \$ 0.167 / \mathrm{kW} \mathrm{h}$ ) is US\$ 0.0025 per treatment ( 1 treatment $=100$ seeds). Due to the advantage of the DBD plasma technique in terms of being chemical-free and environmentally friendly, the expense for the DBD plasma equipment and operating cost is low comparing with the common pre-sowing seed treatments, such as soaking seeds in water or a solution of inorganic substances. These seed treatments typically produce waste that causes environmental concerns [30]. 


\section{CONCLUSION}

This study showed the potential benefits of DBD plasma treatment to improve sunflower seed performance and sprout quality. The optimal DBD plasma exposure time of $120 \mathrm{~s}$ could enhance the germination percentage, reduce germination time, improve sprout growth, and increase the total phenolic (including flavonoid) contents in sunflower sprouts. To produce high bioactivity sunflower sprouts for functional foods, it is recommended that the seeds should be treated with DBD plasma for $120 \mathrm{~s}$ before sprouting.

Acknowledgements: The authors gratefully acknowledge the financial support provided by the Thammasat University Research Fund under the TU Research Scholar, Contract No. 2/22/2561. We are also grateful to Mr. John Winward from Thammasat University for his kind proofreading of our manuscript.

\section{REFERENCES}

1. Chirokov A, Gutsol A, Fridman A (2005) Atmospheric pressure plasma of dielectric barrier discharges. Pure Appl Chem 77, 487-495.

2. Ohta T (2016) Plasma in agriculture. In: Misra NN, SchlÜter O, Cullen PJ (eds) Cold Plasma in Food and Agriculture: Fundamentals and Applications, Academic Press, UK, pp 205-221.

3. Moreau M, Orange N, Feuilloley MGJ (2008) Nonthermal plasma technologies: new tools for biodecontamination. Biotechnol Adv 26, 610-617.

4. Butscher D, Loon HV, Waskow A, von Rohr PR, Schuppler M (2016) Plasma inactivation of microorganisms on sprout seeds in a dielectric barrier discharge. Int J Food Microbiol 238, 222-232.

5. Štěpánová V, Slavíček P, Kelar J, Prášil J, Smékal M, Stupavská M, Jurmanová J, Černák M (2018) Atmospheric pressure plasma treatment of agricultural seeds of cucumber (Cucumis sativus L.) and pepper (Capsicum annuum L.) with effect on reduction of diseases and germination improvement. Plasma Process Polym 15, e1700076.

6. Tong J, He R, Zhang X, Zhan R, Chen W, Yang S (2014) Effects of atmospheric pressure air plasma pretreatment on the seed germination and early growth of Andrographis paniculata. Plasma Sci Technol 16, 260-266.

7. Filatova I, Azharonok V, Kadyrov M, Beljavsky V, Gvozdov A, Shik A, Antonuk A (2011) The effect of plasma treatment of seeds of some grain and legumes on their sowing quality and productivity. Rom $J$ Phys 56, 139-143.

8. da Silva ARM, Farias ML, da Silva DLS, Vitoriano JO, de Sousa RC, Alves-Junior C (2017) Using atmospheric plasma to increase wettability, imbibition and germination of physically dormant seeds of Mimosa caesalpiniafolia. Colloids Surfaces B 157, 280-285.

9. Ling L, Jiafeng J, Jiangang L, Minchong S, Xin H, Hanliang S, Yuanhua D (2014) Effects of cold plasma treatment on seed germination and seedling growth of soybean. Sci Rep 4, ID 5859.

10. Kitazaki S, Sarinont T, Kago K, Hayashi N, Shiratani M (2014) Plasma induced long-term growth enhancement of Raphanus sativus L. using combinatorial atmospheric air dielectric barrier discharge plasmas. Curr Appl Phys 14, 149-153.

11. Dobrin D, Magureanu M, Mandache NB, Ionita MD (2015) The effect of non-thermal plasma treatment on wheat germination and early growth. Innov Food Sci Emerg Technol 29, 255-260.

12. Ji SH, Choi KH, Pengkit A, Im JS, Kim JS, Kim YH, Park Y, Hong EJ, et al (2016) Effects of high voltage nanosecond pulsed plasma and micro DBD plasma on seed germination, growth development and physiological activities in spinach. Arch Biochem Biophys 605, 117-128.

13. Iranbakhsh A, Ghoranneviss M, Ardebili ZO, Ardebili NO, Tackallou SH, Nikmaram H (2017) Non-thermal plasma modified growth and physiology in Triticum aestivum via generated signaling molecules and $\mathrm{UV}$ radiation. Biol Plant 61, 702-708.

14. Iranbakhsh A, Ardebili ZO, Ardebili NO, Ghoranneviss M, Safari N (2018) Cold plasma relieved toxicity signs of nano zinc oxide in Capsicum annuum cayenne via modifying growth, differentiation, and physiology. Acta Physiol Plant 40, ID 154.

15. Pająk P, Socha R, Gałkowska D, Rożnowski J, Fortuna T (2014) Phenolic profile and antioxidant activity in selected seeds and sprouts. Food Chem 143, 300-306.

16. Chaichana N (2019) Analysis of nutritional composition, antioxidant activity and callus induction of Oryza sativa cultivars Khumthan and Norprae. ScienceAsia 45, 509-514.

17. ISTA (2007) International Rules for Seed Testing. International Seed Testing Association, Bassersdorf, Switzerland.

18. Geneve RL (2005) Vigour testing in flower seeds. In: McDonald MB, Kwong FY (eds) Flower Seeds Biology and Technology, CABI Publishing, UK, pp 311-332.

19. Worawattananutai P, Itharat $A$, Ruangnoo $S$ (2014) In vitro antioxidant, anti-inflammatory, cytotoxic activities against prostate cancer of extracts from Hibiscus sabdariffa leaves. $J$ Med Assoc Thai 97, 81-87.

20. Jirakiattikul Y, Rithichai P, Songsri O, Ruangnoo S, Itharat A (2016) In vitro propagation and bioactive compound accumulation in regenerated shoots of Dioscorea birmanica Prain \& Burkill. Acta Physiol Plant 38, ID 249.

21. Zhu H, Wang Y, Liu Y, Xia Y, Tang T (2010) Analysis of flavonoids in Portulaca oleracea L. by uv-vis spectrophotometry with comparative study on different 
extraction technologies. Food Anal Methods 3, 90-97.

22. Yamasaki K, Hashimoto A, Kokusenya Y, Miyamoto T, Sato T (1994) Electrochemical method for estimating the antioxidative effects of methanol extracts of crude drugs. Chem Pharm Bull 42, 1663-1665.

23. Dhayal M, Lee SY, Park SU (2006) Using low-pressure plasma for Carthamus tinctorium L. seed surface modification. Vacuum 80, 499-506.

24. Šerá B, Špatenka P, Šerý M, Vrchotová N, Hrušková I (2010) Influence of plasma treatment on wheat and oat germination and early growth. IEEE Trans Plasma Sci 38, 2963-2968.

25. Jiafeng J, Xin H, Ling L, Jiangang L, Hanliang S, Qilai X, Renhong Y, Yuanhua D (2014) Effect of cold plasma treatment on seed germination and growth of wheat. Plasma Sci Technol 16, 54-58.

26. Mihai AL, Dobrin D, Măgureanu M, Popa ME (2014) Positive effect of non-thermal plasma treatment on radish seeds. Rom Rep Phys 66, 1110-1117.

27. Bußler S, Herppich WB, Neugart S, Schreiner M,
Ehlbeck J, Rohn S, Schlüter O (2015) Impact of cold atmospheric pressure plasma on physiology and flavonol glycoside profile of peas (Pisum sativum 'Salamanca'). Food Res Int 76, 132-141.

28. Zhang B, Li R, Yan J (2018) Study on activation and improvement of crop seeds by the application of plasma treating seeds equipment. Arch Biochem Biophys 655, 37-42.

29. Šerá B, Gajdová I, Černák M, Gavril B, Hnatiuc E, Kováčik D, Kř́íha V, Sláma J, et al (2012) How various plasma sources may affect seed germination and growth. In: 13th International Conference on Optimization of Electrical and Electronic Equipment (OPTIM), Brasov, Romania, pp 1365-1370.

30. Mitra A, Li YF, Klämpfl TG, Shimizu T, Jeon J, Morfill GE, Zimmermann JL (2014) Inactivation of surfaceborne microorganisms and increased germination of seed specimen by cold atmospheric plasma. Food Bioprocess Technol 7, 645-653. 